\title{
VÝSKUMY LOKALITY DUWEJM WAD HADŽ V SUDÁNE V ROKOCH 2017 A $2018^{1}$
}

\author{
Jozef Hudec - Michal Cheben - Branislav Kovár
}

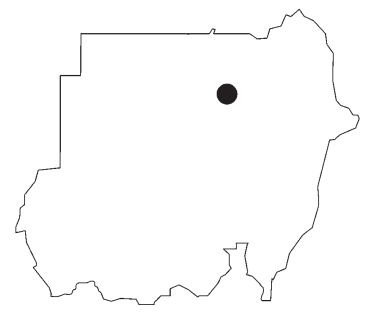

DOI: https://doi.org/10.31577/szausav.2019.65.10

Key words: Sudan, Duweym Wad Haj, geophysical research, Islamic architecture, mosque, qubba

Research at Duweym Wad Haj in the Sudan in 2017 and 2018 Seasons

In 2017 and 2018 seasons, archaeological research and geophysical research was made at the Sudanese archaeological site of Duweym Wad Hajj. Research has identified a number of underground structures that, along with discovered pottery material, could be an indication of an older settlement. Previous site surveys predicted the existence of ancient architecture here. In addition to the geophysical survey, the old mosque was documented at the site.

\section{ÚVOD}

Sudán stále patrí medzi menej archeologicky preskúmané krajiny, hoci sa tu nachádza viacero pamiatok patriacich $\mathrm{k}$ svetovému historickému a kultúrnemu dedičstvu. V snahe vyrovnat túto nerovnost', tu každoročne báda viacero zahraničných vedeckých expedícií. Od roku 2018 sa k nim pripojil aj slovenský tím. Práca prináša predbežnú správu o prvých výskumných sezónach lokality Duwejm Wad Hadž. „Slovenský výskum na sudánskej lokalite Duwejm Wad Hadž“ je spoločným projektom Ustavu orientalistiky SAV v Bratislave, Archeologického ústav SAV v Nitre a nadácie Aigyptos.

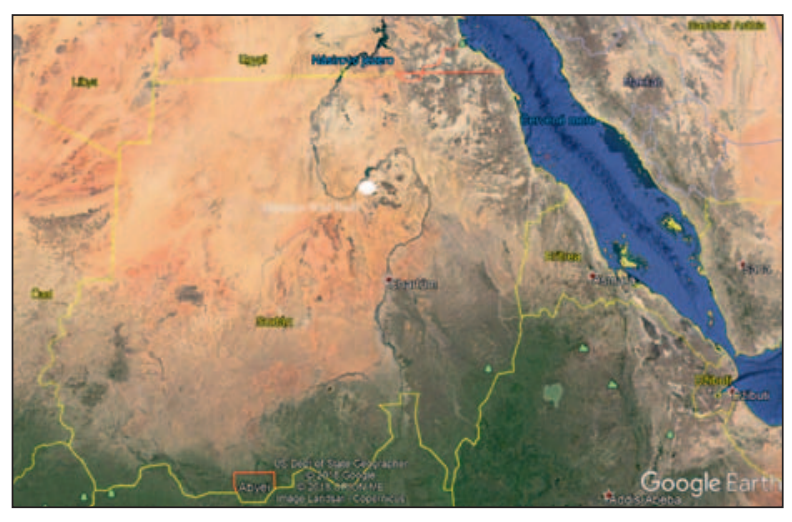

Obr. 1. Duwejm Wad Hadž. Poloha lokality na Google Earth.

Lokalita Duwejm Wad Hadž sa nachádza v Severnej provincii (Wilajet aš-Šamalíja), asi $350 \mathrm{~km}$ severne od Chartúmu, vo Vel'kom nílskom ohybe. Na lavom brehu Nílu je to asi $30 \mathrm{~km}$ juhozápadne, t. j. po prúde od priehrady Merowe, ktorú postavili na štvrtom nílskom katarakte (obr. 1). Oproti Duwejmu, cez rieku, sa rozprestiera jedna z najvýznamnejších sudánskych archeologických lokalít Džebel Barkal. Spolu s d’alšími okolitými lokalitami je zapísaná aj v zozname svetového kultúrneho dedičstva UNESCO. V 2. tisícročí pred Kr. tu starí Egyptania adaptovali prírodný skalný útvar ako kultové centrum boha Amona (Kendall 1990), pričom pravdepodobne nadviazali na miestne tradície (Kendall 2002, 6). Nachádzalo sa tu tiež napatské královské sídlo s pohrebiskom a osídlenie pokra-

čovalo aj v merojskom období (Edwards 2004, 16, 154, 155, 181;'2 2007, 219, 220).

Vzdialenost' lokality Duwejm Wad Hadž od rieky Níl je asi 900 m na juhovýchod od jej lavého brehu. Po prúde rieky sa nachádza lokalita Sanam s chrámom, ktorý objavil výskum Oxfordskej univerzity v rokoch 1912-1913 (Griffith 1922, 67-124; 1923, 73-171) a osídlením z napatského obdobia (Edwards 2004, 133-135).

1 Práca vznikla v rámci projektu APVV-17-0579 „Slovenský výskum na sudánskej lokalite Duwejm Wad Hadž“. Je skrátenou a upravenou verziou predbežnej správy, ktorá je odovzdaná sudánskej NCAM pre publikovanie.

2 Tam aj d’alšia literatúra k lokalite Džebel Barkal. 


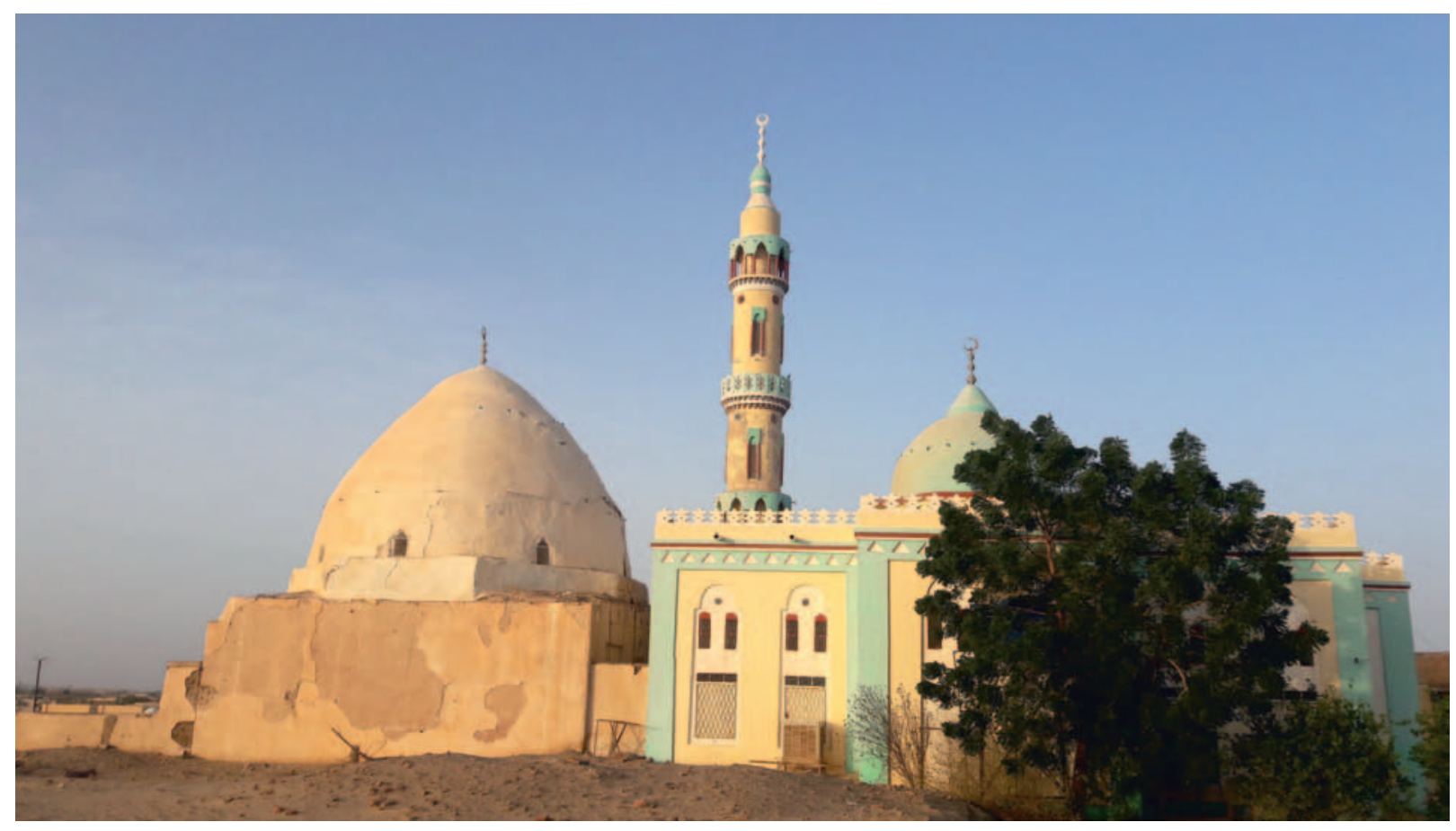

Obr. 2. Duwejm Wad Hadž. Mladšia mešita a gubba. Foto B. Kovár.

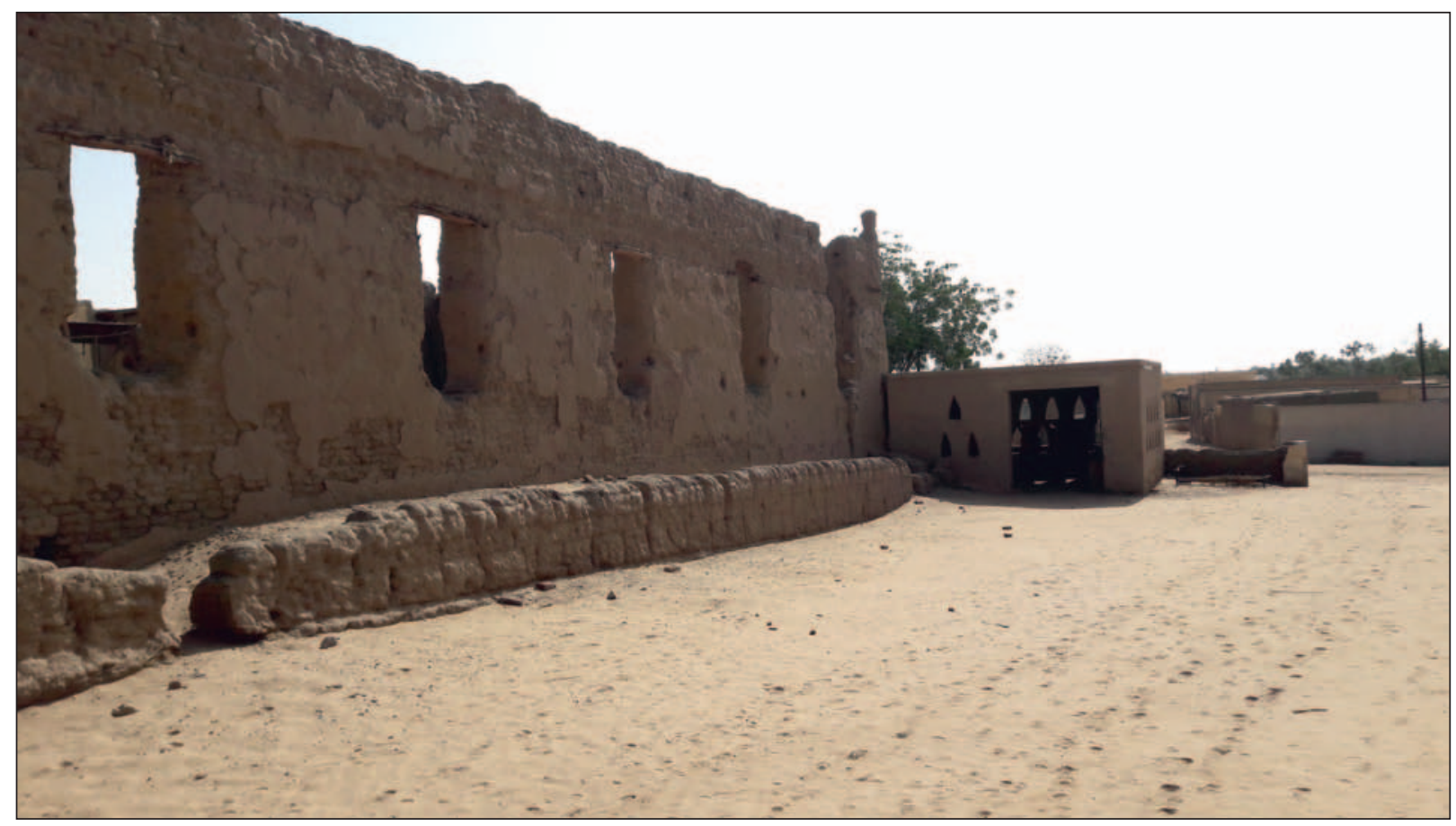

Obr. 3. Duwejm Wad Hadž. Zachovaný severný múr staršej mešity. Foto B. Kovár. 


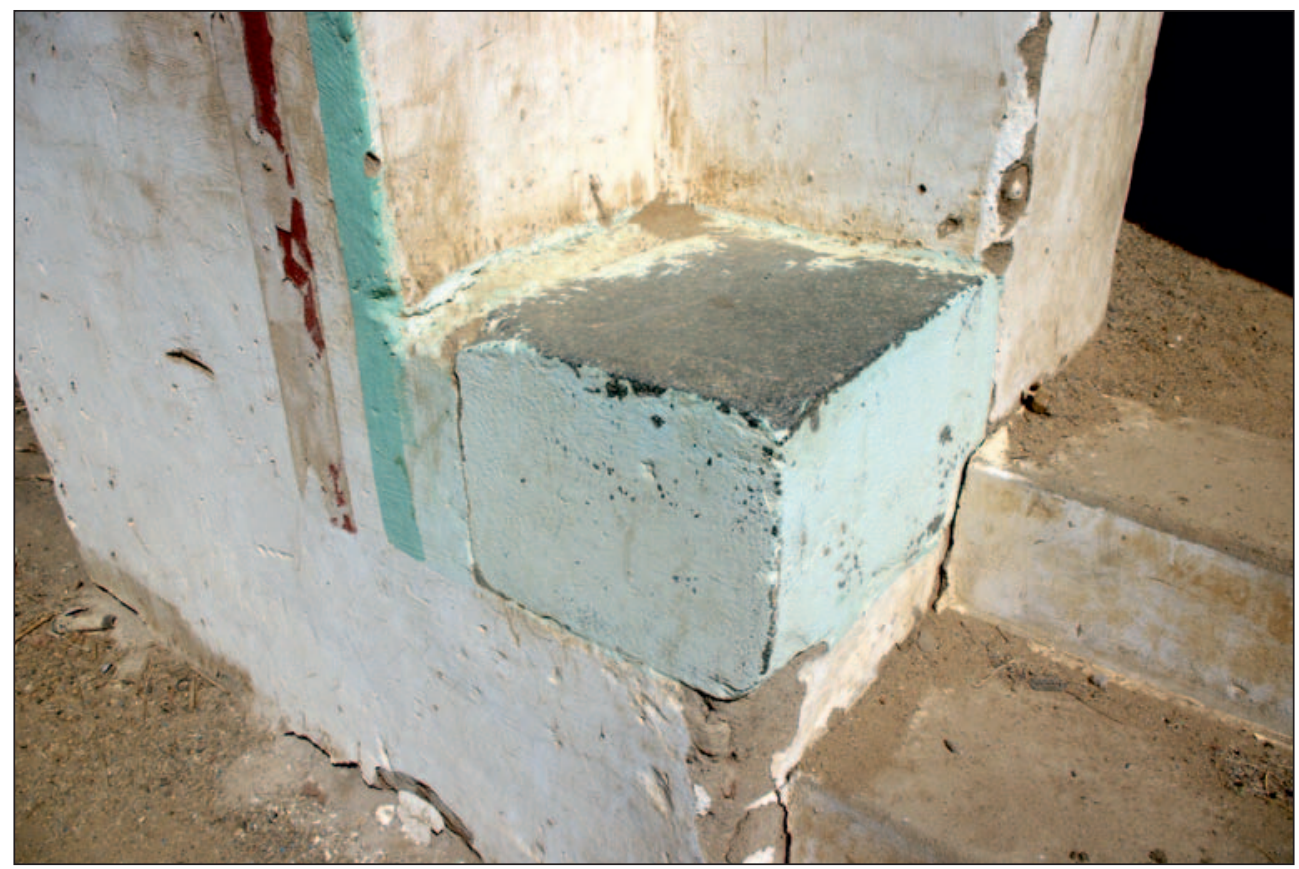

Obr. 4. Duwejm Wad Hadž. Pomal'ovaný kamenný kváder na lavej strane západnej vstupnej brány. Foto J. Hudec.

Lokalitu v Duwejme objavil sudánsky archeológ Faiz Hassan Osman. Spoluriaditel misie National Corporation for Antiquities and Museums of the Sudan/NCAM v Džebel Barkale, T. Kendall, opísal lokalitu po svojich prieskumoch v okolí v roku 2009. Predpokladal tu staroveký chrám so vztahom k lokalite Džebel Barkal (Kendall 2010), nakol'ko Duwejm mohol byt๋ východiskom ciest spájajúcich Džebel Barkal cez údolie (wádí) Abú Dom ${ }^{3}$ a d’alej cez Bajúdsku púšt so sútokom riek Níl, Atbara, resp. s královským sídlom v Meroe. Informácie T. Kendalla zaujali v roku $2015 \mathrm{~J}$. Hudeca a prispeli k rozhodnutiu požiadat’ NCAM o povolenie archeologického výskumu. V novembri 2017 uskutočnil J. Hudec na lokalite krátky prieskum (Hudec 2017).

Lokalita Duwejm Wad Hadž má charakter menšieho tellu, ktorý sa nachádza na a pod pieskovcovým výbežkom, prevýšeného asi 5-6 m nad okolitým terénom na rozhraní nílskej nivy a púštnej terasy. Na vyvýšenine sa nachádzajú dve mešity a zaklenutá hrobka typu gubba (qubba, ق. t. t. j. kupola) islamského zbožného muža (obr. 2; Trimingham 1965, 128). Gubba nebola zatial' bližšie preskúmaná, nie je presne datovaná, ani zaradená do regionálneho typologického konceptu (Elsadig 2000, 37-43). Stará severnejšia $\mathrm{z}$ mešít takisto nie je datovaná a je $\mathrm{v}$ dezolátnom stave. Južný múr starej mešity je zrútený a priestor pri jej juhozápadnom rohu zaberá čast novej južnejšej mešity. Východný, severný a čast’ západného múru sa zachovali do úrovne bývalej strechy (obr. 3), identifikovanej iba v oblasti zastrešenia západnej vstupnej brány. Mladšia (v súčasnosti používaná) mešita je pravdepodobne z konca 20. stor. Západná vstupná brána do starej mešity je na úrovni horného vyústenia schodov z každej strany a zrkadlovo je lemovaná po jednom kvádre z tvrdého kameňa (pravdepodobne čierna žula). Nie je vylúčené, že oba kvádre spolu pôvodne tvorili dlhší hranolovitý celok. Z čelnej strany sú pomalované zelenou farbou, podobne ako brána mešity (obr. 4). Po l’avej strane brány sa pred obvodovým múrom nachádzal opracovaný blok z rovnakého materiálu, ako vyššie uvedené kvádre. Pravdepodobne ide o torzo chrámového schodiska. Spomínané kamenné kvádre môžu pochádzat bud' zo staršej stavby pod mešitou, alebo sem mohli byt’ transportované z okolitých lokalít (Džebel Barkal, Sanam, ap.).

Okolie aj vnútro starej mešity sú pokryté jemným žltým pieskom. Východne od novej mešity sa nachádza vrstva štrkopiesku so sporadickými drobnými nediagnostickými úlomkami keramiky, ktorá je využívaná na pochovávanie na recentnom moslimskom pohrebisku.

Charakter lokality, jej poloha, publikované informácie a povrchové nálezy jednoznačne indikovali prítomnost' archeologickej lokality.

\footnotetext{
Wadi Abu Dom Itinerary, http://en.wadi-abu-dom.de/
} 


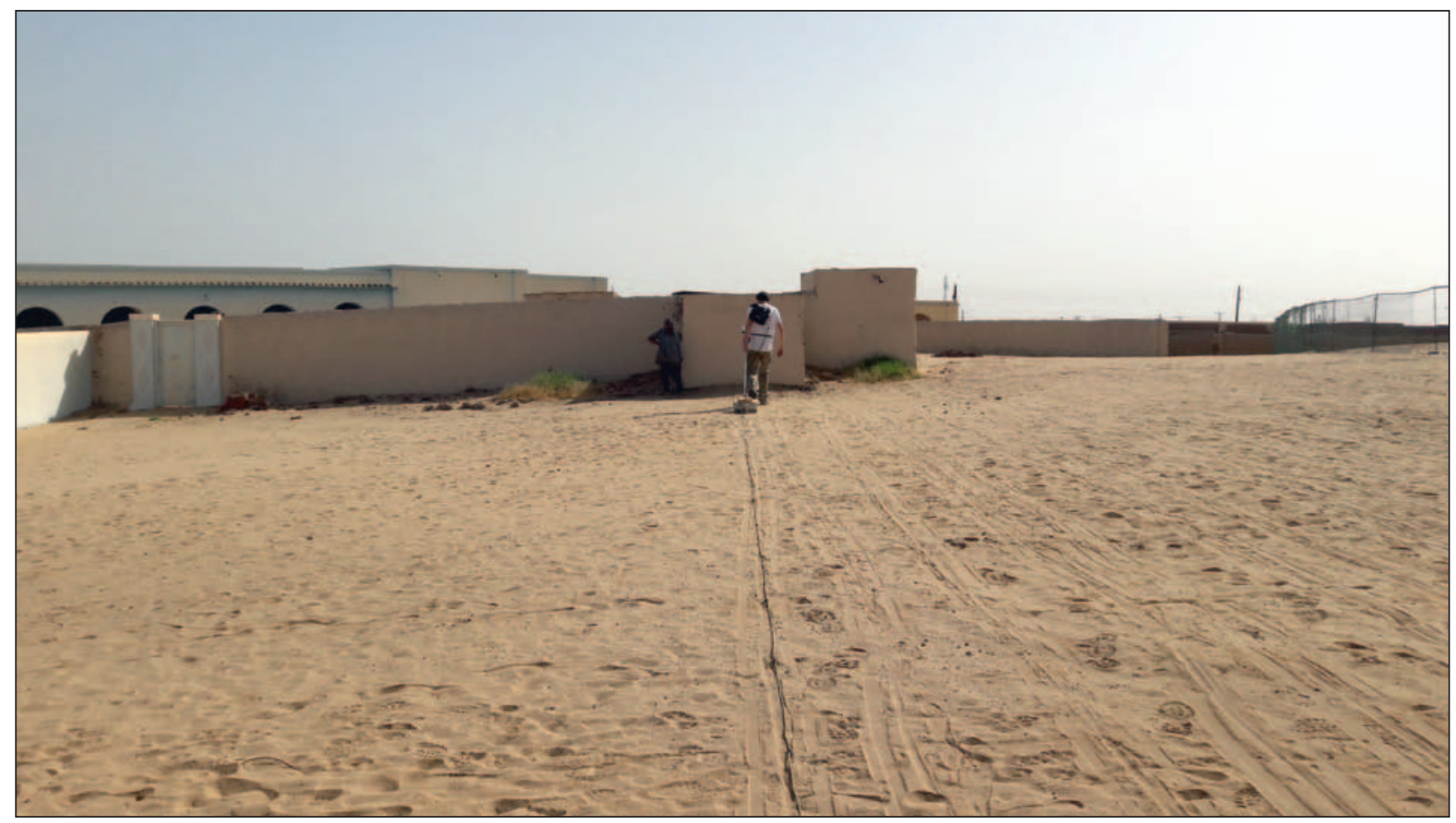

Obr. 5. Duwejm Wad Hadž. Geofyzikálny výskum pomocou Ground Penetration Radar. Foto B. Kovár.

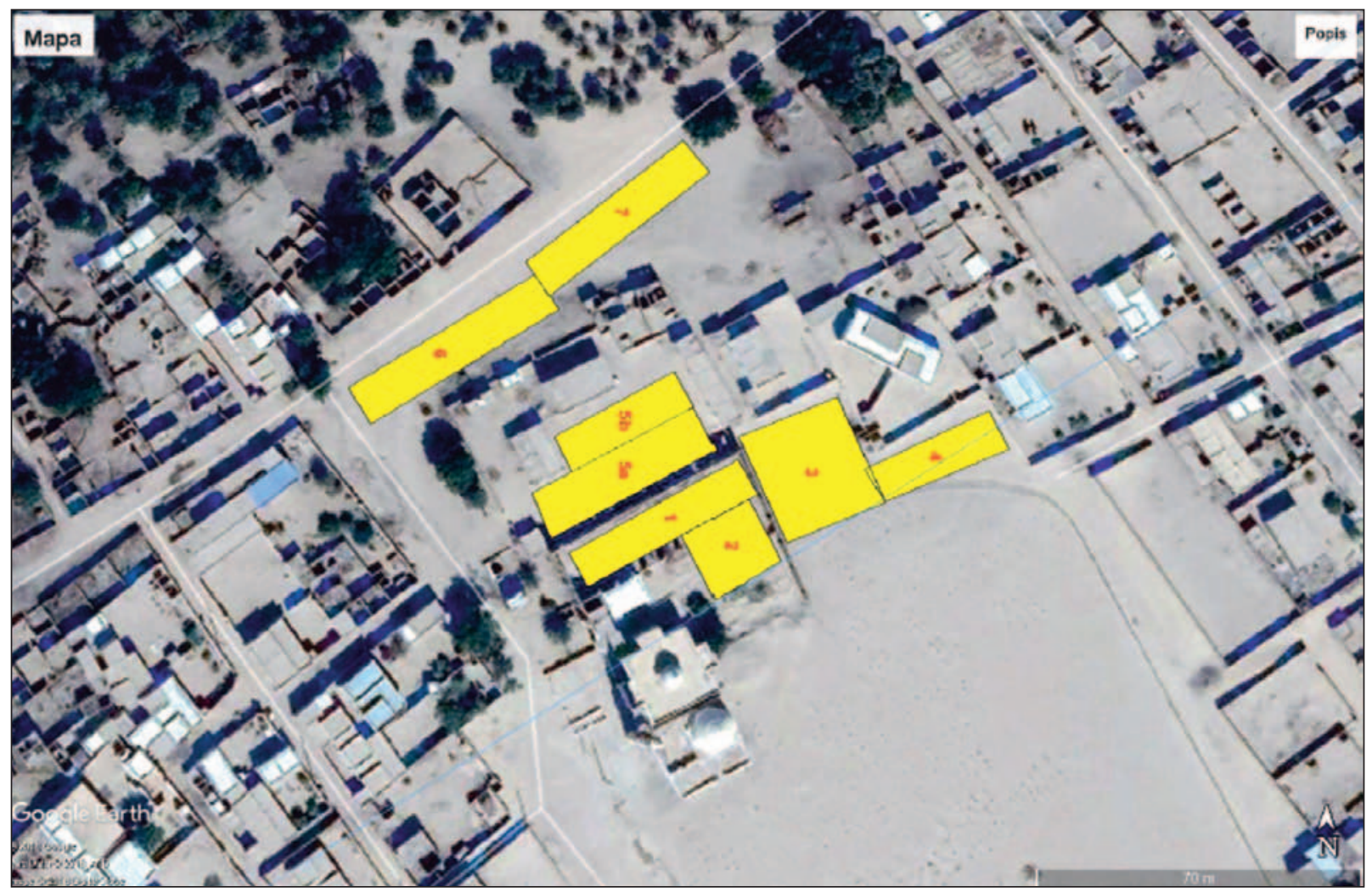

Obr. 6. Duwejm Wad Hadž. Priestor geofyzikálneho výskumu. Foto M. Cheben. 


\section{GEOFYZIKÁLNY VÝSKUM V ROKU 2018}

V dňoch 21. až 25. februára 2018 vykonali na lokalite Duwejn Wad Hadž autori článku (za slovenskú stranu) a inšpektorka Mundžida Chalídová (za sudánsku stranu) geofyzikálny výskum, architektonickú dokumentáciu staršej mešity a archeologickú prospekciu.

Prieskum sa realizoval pomocou georadaru. Cielom bolo zachytit pozostatky predpokladanej zaniknutej architektúry. Na prieskum bol použitý Ground Penetration Radar/GPR (RAMAC) systém X3M s $500 \mathrm{MHz}$ anténou. Na vytýčených plochách sa merali jednotlivé profily v rozstupe $0,5 \mathrm{~m}$ (obr. 5). Po softvérom spracovaní v programe ReflexW sa získali vertikálne georadarové profily, ktoré sa spojili do horizontálnych časových snímok. Híbka dosahu antény na danej lokalite bola zadaná do 3,4 m. Jednotlivé plochy boli po meraní geodeticky zamerané pomocou GPS prístroja TrimbleR2. ${ }^{4}$

Geofyzikálny prieskum bol na výraznej terénnej elevácii, v priestoroch zaniknutej mešity, ako aj východne a severne od nej. Priestor výskumu bol rozdelený na osem plôch (obr. 6). Povrch terénu tvorila vrstva s hlinou premiešaného piesku, ktorý nasadal na pieskovcové podložie. Na plochách 6 a 7 bola situácia rozdielna, vrchná vrstva piesku nasadala na fluviálne hliny rieky Níl.

Po softvérovom spracovaní nameraných dát z jednotlivých plôch a vyhotovení horizontálnych časových rezov sa ukázali viaceré štruktúry indikujúce archeologické situácie, pričom niektoré štruktúry môžu byt๋ zvyškami starších architektúr.

\section{Plocha 1}

V severnej časti staršej nepoužívanej mešity sa našli viaceré štruktúry, ktoré by mohli naznačovat’ zaniknutú architektúru, resp. pozostatky po ludskej činnosti. V híbke 0,4 m sa nachádzala štruktúra 1, ktorá bola v blízkosti štruktúry 2. Jej tvar je v tvare písmena L. Celkové rozmery sa nedali určit, pretože štruktúra nebola v celom rozsahu.

V híbke $30 \mathrm{~cm}$ sa na horizontálnom časovom snímku plochy 1 nejasne objavila štruktúra 2. Na d’alších časových snímkach sa črtala už zretel’nejšie. Šírka je 3,5 m. Dĺžka nebola určená, pretože nebola celá. Štruktúra sa našla v híbke $0,7 \mathrm{~m}$. Mohlo by íst' o pozostatok zaniknutej architektúry.

Na horizontálnom časovom snímku v híbke $0,5 \mathrm{~m}$ sa objavila štruktúra 3. Jej pôdorys je obdížnikovitého tvaru so šírkou okolo $1 \mathrm{~m}$. Dížka sa určit nedala. Štruktúra 3 sa objavuje do híbky $0,7 \mathrm{~m}$. Štruktúry 2 a 3 môžu spolu súvisiet. V híbke 0,5-0,6 m sa nezretelne našla dalšsia štruktúra interpretovaná ako základ stavby so šírkou $1 \mathrm{~m}$. Nakol'ko sa nenašla na d’alších časových rezoch je pravdepodobné, že radar zachytil len negatív po murive. Samotné podložie sa nachádza v híbke $0,8-1,2 \mathrm{~m}$. Štruktúry na ploche 1 by mohli súvisiet so staršími stavbami, prípadne s infraštruktúrou staršej mešity (tab. I: 1).

\section{Plocha2}

V juhovýchodnom kvadrante staršej mešity sa našli viaceré štruktúry, ktoré by tiež mohli naznačovat prítomnosť zaniknutej architektúry, resp. pozostatky po ludskej činnosti. V híbke tesne pod povrchom sa objavila líniová štruktúra, ktorá možno indikuje inžiniersku siet̉ alebo starší výkop. V híbke od 0,4 m sa na horizontálnych časových rezoch našla menšia štvorcová štruktúra 4 (tab. I: 2) s rozmermi 1,5 x 1,5 m. Mohlo by íst' o pozostatok zaniknutej architektúry. Samotné podložie sa nachádza v híbke 1-1,3 m.

\section{Plocha 3}

Priliehajúcej k východnej strane staršej mešity, georadar zaznamenal viaceré štruktúry, ktoré by mohli naznačovat zaniknutú architektúru, resp. pozostatky po ludskej činnosti. V híbke $0,3-1,0 \mathrm{~m}$ sa objavila štvorcová štruktúra $5 \mathrm{~s}$ rozmermi $2,5 \times 2,5 \mathrm{~m}$. Pravdepodobne je to pozostatok zaniknutej architektúry. V híbke $0,4 \mathrm{~m}$ sa na horizontálnom časovom reze objavila výrazná kruhová štruktúra so štvorcovým výbežkom číslo 6 (tab. I: 3). Táto štruktúra je dobre badatelná do híbky $0,7 \mathrm{~m}$. Jej rozmery sú $4 \mathrm{x}$ $4 \mathrm{~m}$. Samotné podložie sa nachádza v híbke 1,2-1,6 m.

\footnotetext{
4 Prístroj zapožičal Ing. R. Hrdlovič, konatel’ obchodnej spoločnosti Geotronics Slovakia, s. r. o.
} 


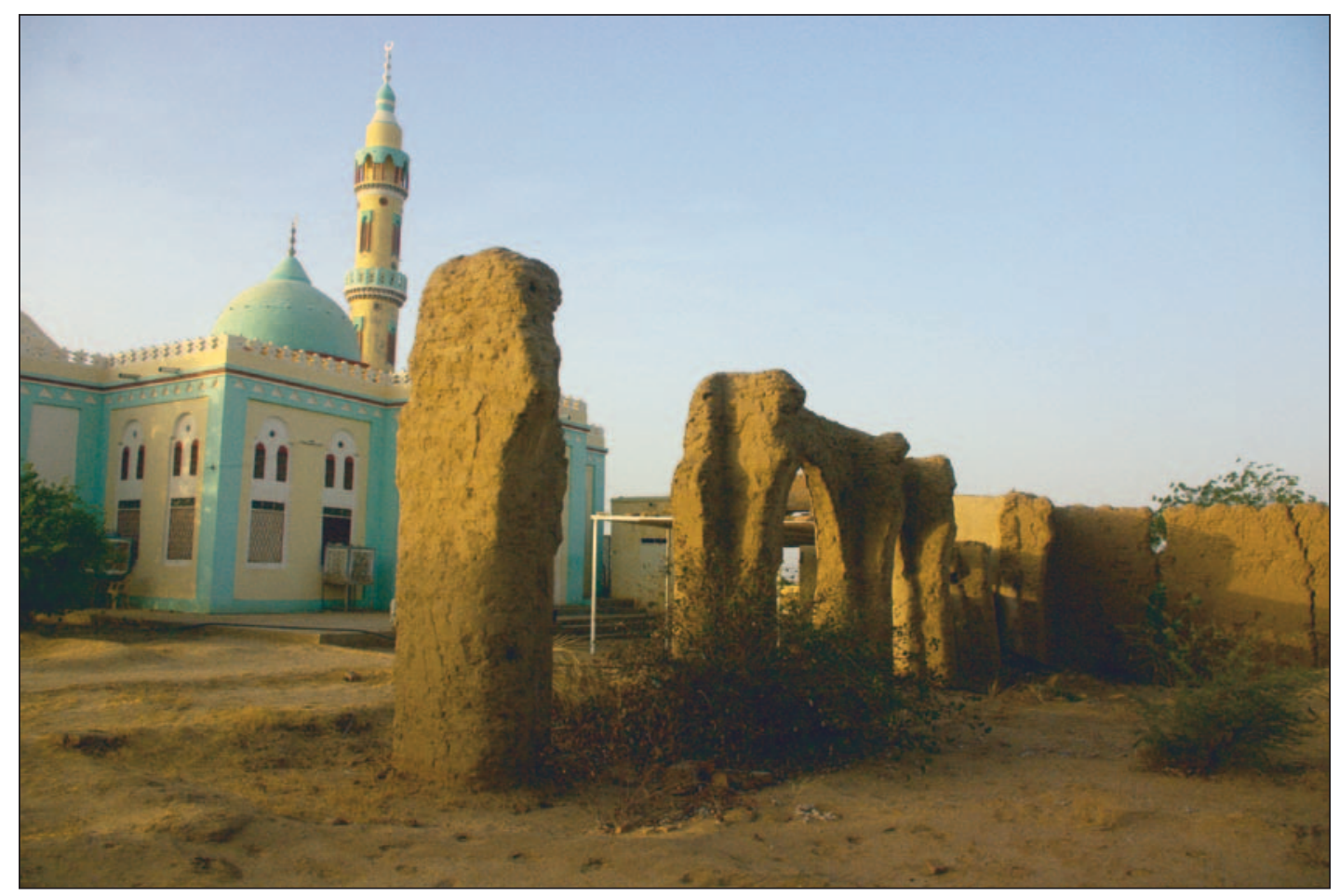

Obr. 7. Duwejm Wad Hadž. Zachované zvyšky riváku. Foto J. Hudec.

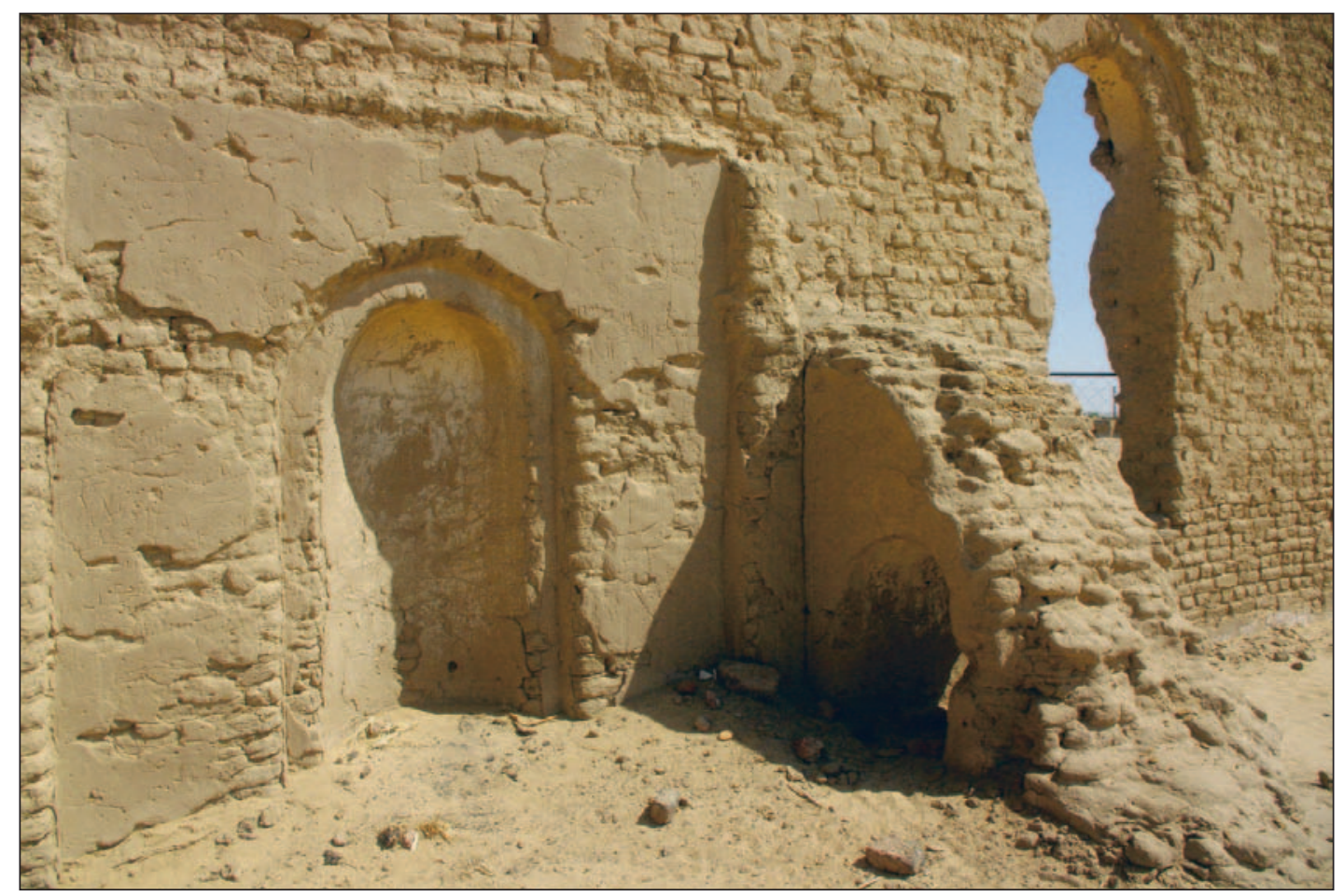

Obr. 8. Duwejm Wad Hadž. Mihráb, lemovaný na stene ozdobným rámcom medzi oknom a minbarom. Foto J. Hudec. 


\section{Plocha 4}

Východne od plochy 3 sa objavila jedna štruktúra, ktorá by mohla naznačovat zaniknutú architektú$\mathrm{ru}$, resp. pozostatky po ludskej činnosti. $\mathrm{V}$ híbke $0,4 \mathrm{~m}$ sa na horizontálnom časovom reze našla štvorcová štruktúra 7, pokračuje do híbky $0,9 \mathrm{~m}$. Jej rozmery sú asi $1 \times 1 \mathrm{~m}$. Mohlo by íst tiež o pozostatok zaniknutej architektúry (tab. I: 4). Podložie sa v tejto oblasti nachádza v híbke približne 1,6-2 m.

\section{Plocha 5a}

Na ploche 5a, priliehajúcej k severnej stene nepoužívanej mešity, sa našli viaceré štruktúry, ktoré by mohli naznačovat zaniknutú architektúru, resp. pozostatky ludskej činnosti. V híbkach 0-1 m sa na meranej ploche nenašla súvislá štruktúra, našli sa však viaceré anomálie indikujúce solitérne bloky/ kusy pravdepodobne kameňov. V híbke 1,3 m bola štruktúra číslo 8 (tab. I: 5) badatelná do híbky 1,8 m. Mohlo by íst o pozostatok základov stavby. V pôdoryse má tvar písmena L. Čast tejto stavby pokračuje pod múrik pri zaniknutej mešite. $\mathrm{V}$ juhovýchodnej časti má táto štruktúra tvar akoby štvorca s rozmermi približne $8 \times 8 \mathrm{~m}$. V híbke $1,9 \mathrm{~m}$ sa našla líniová štruktúra číslo $9 \mathrm{~s}$ mierne zaobleným tvarom (tab. II: 1). Pokračuje aj na ploche $5 \mathrm{~b}$, kde po pár metroch končí. Tak isto by mohlo íst’ o zaniknutú architektúru. Samotné podložie sa nachádza v hlbke asi $2-2,4 \mathrm{~m}$.

\section{Plocha $5 b$}

Na ploche $5 \mathrm{~b}$, nadväzujúcej na severný okraj plochy $5 \mathrm{a}$, sa našla jedna štruktúra, ktorá by mohla naznačovat’ zaniknutú architektúru, resp. pozostatky ludskej činnosti. V híbke 0,2 m sa na horizontálnom časovom snímku objavila štvorcová štruktúra 10 (tab. II: 2) s rozmermi $1 \times 1 \mathrm{~m}$. Mohlo by íst̉ o pozostatok zaniknutej architektúry. Samotné podložie bolo v híbke zhruba 1,2-2 m.

\section{Plocha 6}

Severne od staršej mešity, na pomedzí tellu a nílskej nivy, bola jedna štruktúra, ktorá by mohla naznačovał’ zaniknutú architektúru, resp. pozostatky ludskej činnosti. V híbke od 0,4 do 0,7 m sa objavila líniová štruktúra 11 (tab. II: 3), ktorá by mohla naznačovat pozostatok zaniknutej architektúry. Samotné podložie bolo v híbke asi $1,2 \mathrm{~m}$.

\section{Plocha 7}

Východne od plochy 6 sa nenašli žiadne štruktúry indikujúce zaniknutú architektúru, resp. pozostatky po staršej ludskej činnosti. Geofyzikálny prieskum objavil viacero možných architektúr, avšak ich relevantnost' overí až d’alší komplexný archeologický výskum.

\section{DOKUMENTÁCIA STAREJ MEŠITY}

Výskumný tím uskutočnil aj základné zdokumentovanie starej mešity. Jej pôdorys je mierne nepravidelný, s rozmermi približne 45,5 m (severný múr, SZ - SV), 36,3 m (východný múr, SV - JV), 44 m (južný múr, JV - JZ, ruina múru sledovatel’ná v dížke asi $23 \mathrm{~m}$ ) a asi $33 \mathrm{~m}$ (západný múr, JZ - SZ, múr zachovaný $\mathrm{v}$ dížke pravdepodobne $23 \mathrm{~m}$ ). Paralelne so severnou stenou mešity, vo vzdialenosti asi 11,8 m od steny, sa zachoval zvyšok riváku (riwāq, رواق, vnútorná arkáda mešity; obr. 7; Hattstein/Delius 2007, 611) v dížke takmer $25 \mathrm{~m}$. Nie je však vylúčené, že ide iba o rakúbu, tieniaci prístrešok, bežný v sudánskych mešitách (Trimingham 1965, 122).

V centre východnej (SV - JV) steny sa zachoval polkruhový výklenok mihráb (mihrāb, , Hattstein/ Delius 2007, 610) indikujúci kiblu, v sudánskej výslovnosti giblu (qibla, قبلة, Hattstein/Delius 2007, 611), t. j. smer modlitby smerom k Mekke (obr. 8). Pri overení orientácie kiblovej steny mešity na googlemaps 


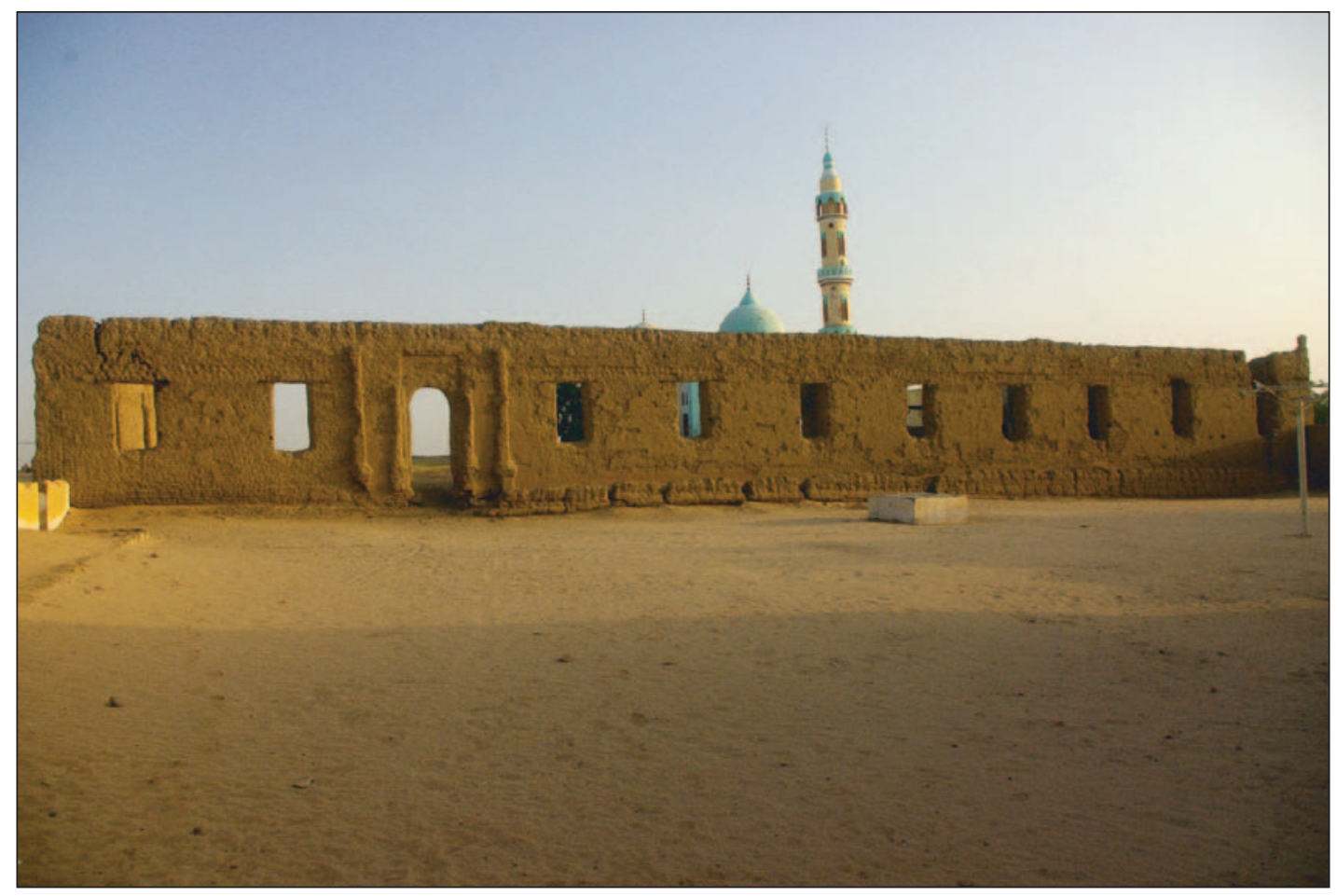

Obr. 9. Duwejm Wad Hadž. Zachovaná severná stena starej mešity. Foto J. Hudec.

vykazuje táto stena presné zameranie na saudskoarabskú Kaabu v známej hlavnej mešite islamu (Masdžid al-Harám).

Mihráb, lemovaný na stene ozdobným rámcom medzi oknom a minbarom, však nie je umiestnený symetricky medzi tretím a štvrtým oknom zo šiestich okien kiblovej steny. Toto usporiadanie spôsobil minbar (minbar, jư, t. j. kazatel'nica; obr. 8, Hattstein/Delius 2007, 610), postavený vpravo od mihrábu.

V severnej (SZ - SV) stene mešity sa zachovalo 10 okien a bočný vchod (obr. 9). S výnimkou vchodu je povrch steny z vonkajšej strany nedekorovaný a architektonicky nečlenený. Vonkajšia strana vchodu je vo výklenku, ktorý je lemovaný z každej strany dvojicou erodovaných polostĺpov a erodovaných polopilierov (?). Vnútorná strana vchodu je lemovaná z každej strany erodovaným polopilierom (?). Bočný vstup je medzi ôsmym a deviatym oknom, t. j. v blízkosti SV rohu mešity. Prvé okno v JZ rohu je už zhora erodované a jeho horný oblúk je deštruovaný. Na vonkajšej strane steny je nízka podporná (?) stienka, tiahnuca sa od SZ rohu k bočnému vchodu mešity. Asi metrový priestor medzi stenou a stienkou je vyplnený nepravidelnou vrstvou piesku. Na niektorých miestach piesok odkrýva niekol'ko vrstiev omietky, najvrchnejšia vrstva je malovaná ružovou farbou (pravdepodobne s využitím drveného ružového núbijského pieskovca). Pri vonkajšej strane SZ rohu starej mešity stojí tradičný prístrešok (mazīra, خزيرة) pre "chladiace“ nádoby na vodu (zīr, زيد, Fahmi 2014, 97).

Vnútorná strana severnej (SZ - SV) steny je rozčlenená erodovanými polostlpmi alebo piliermi. Tie sú vyčlenené z muriva steny na polceste medzi jednotlivými oknami, nie však úplne pravidelne. Virtuálne spojnice medzi polostĺpmi/piliermi steny a vnútornou stranou riváku nie sú v pravidelných rozstupoch a nie sú paralelné. Vzhl’adom na vzdialenost medzi severnou stenou a rivákom by sa dal v medzipriestore očakávat’ d’alší rad či rady (drevených/surovicových) stípov, pilierov, ktoré mohli slúžit na podopretie predpokladaného zastrešenia riváku, resp. rakúby.

Vysoké okná mešity sú z vnútornej strany klenuté. Tieto klenby sú na vonkajšej strane preložené drevenými doskami a vyplnené nepálenými tehlami. Okná tak majú z vonkajšej strany obdĺžnikový tvar. V kiblovej stene sú konštruované podobne, ale sú ovela erodovanejšie.

Západná stena mešity sa zachovala iba od SZ rohu po hlavný západný vchod. V murive vonkajšej strany západnej steny sú plasticky vytvarované dva nepravé vstupy (obr. 10). Na vnútornej strane západnej steny nie sú žiadne stopy ani po vchode, ani po jeho prípadnej tehlovej výplni. Dva dalšie takéto nepravé vchody sa mohli nachádzat aj na chýbajúcej časti západnej steny. V blízkosti SZ rohu mešity je 


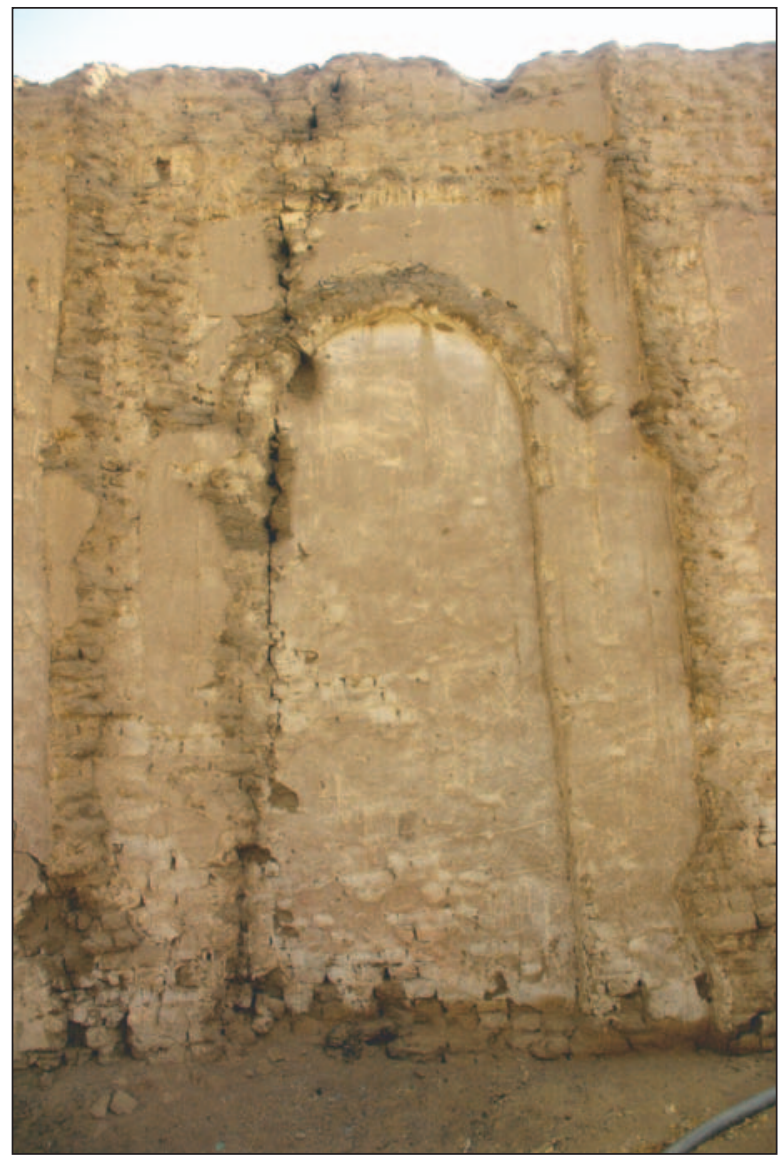

Obr. 10. Duwejm Wad Hadž. Nepravý vchod vytvarovaný v murive vonkajšej strany západnej steny. Foto J. Hudec.

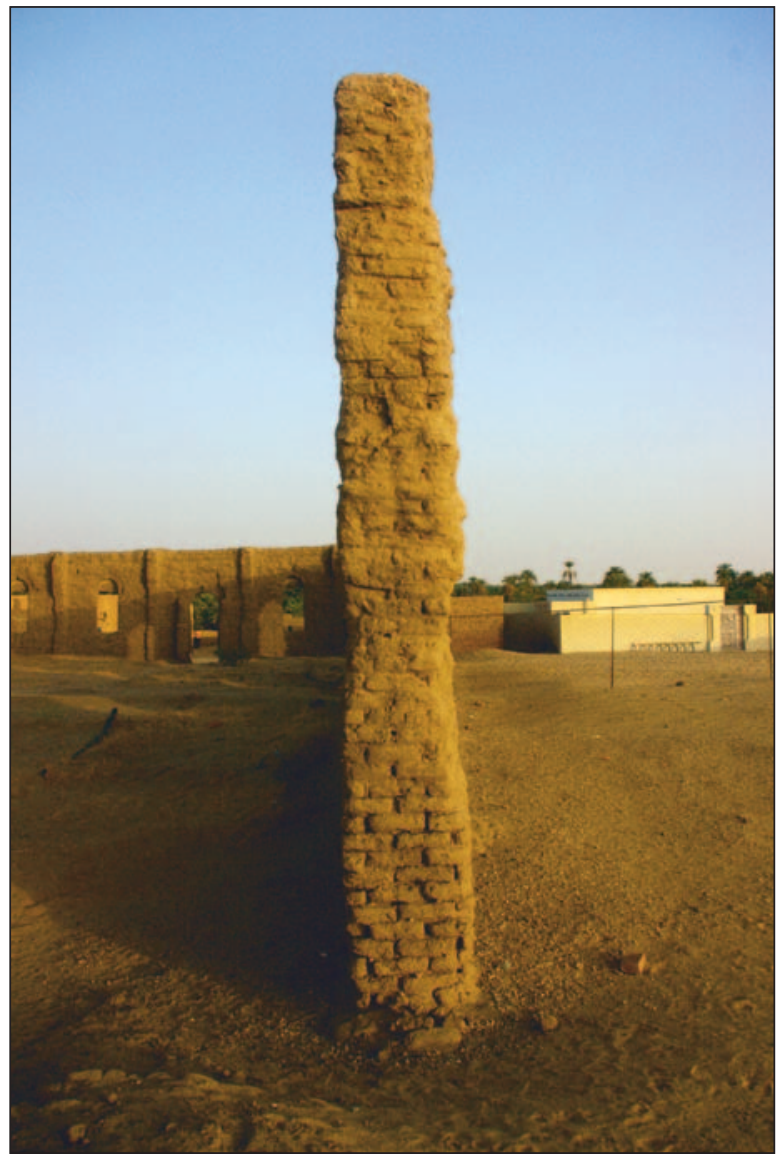

Obr. 11. Duwejm Wad Hadž. Prierez tehlovej väzby a múru v juhovýchodnom rohu mešity. Foto J. Hudec.

kmeň palmy, ktorý bol pravdepodobne použitý na stabilizáciu základov starej mešity. Murivo južnej steny je kompletne zrútené, sú však viditel’né zvyšky nepálených tehiel.

Nepálené tehly, surovice, boli v múroch ukladané v krížovej väzbe, t. j. strieda sa rad tehiel kladený dlhšou stranou do líca muriva na (či pod) rade tehiel kladený kratšou stranou do líca muriva, pričom dlhé tehly sú $\mathrm{v}$ radoch nad sebou o pol dížky posunuté. Prierez tehlovej väzby je viditelný v JV rohu mešity (obr. 11). Zdá sa, že hrúbka steny bola 2,5 dížky tehál $(a s i 45 \mathrm{~cm}$ ) až do úrovne parapetov okien. Nad touto úrovňou sú steny tenšie, približne na dížku dvoch dlhých tehál (t. j. min. $36 \mathrm{~cm}$ ).

Podla vyjadrenia niektorých miestnych obyvatelov bola mešita pravdepodobne postavená v 20. rokoch 19. stor. Toto datovanie by kládlo výstavbu architektúry do začiatku tzv. turkíje, t. j. dobytia Sudánu egyptským vládcom Mohamedom Alím (Trimingham 1965, 91-93), ale datovanie by malo byt overené d’alším výskumom a odobratím vzoriek, napr. z drevených prekladov okien mešity.

Stará mešita je pre predpokladané skromné miestne vidiecke podmienky pozoruhodne vel'ká, má takmer $1600 \mathrm{~m}^{2}$. To je väčšia plocha než u mešity Zawijív starom sudánskom prístavnom meste Suakin (Greenlaw 2015), ktoré bolo častou Osmanskej ríše, alebo je porovnatelná s Vel'kou mešitou (Mesdžid al-Kabír) v Chartúme, ${ }^{5}$ ktorá má cez $2000 \mathrm{~m}^{2}$. Napriek nedostatku starších príkladov sudánskej islamskej architektúry, kvôli prevažujúcemu využívaniu surovíc, opúštaniu, rozpadu starších architektúr a jednoduchosti sudánskeho súfizmu (El-Zein 2000, 34), má islam v oblasti štvrtého nílskeho kataraktu dlhšiu tradíciu (Abdelrahman 2014, 201-208) a o to zaujímavejšiu príležitost’ pre architektonický výskum predstavuje stará mešita (Smith 2013).

Počas sezóny 2018 misia uskutočnila aj archeologický prieskum lokality a jej okolia. Lokalitu sme zamerali pomocou satelitného prijímača Trimble R2 GNSS.

\footnotetext{
5 Vel'ká mešita bola postavená v 19. stor. a po mahdistickom povstaní obnovená na začiatku 20. stor. (Salomon 2016, 46).
} 
Najviac črepového materiálu sa sústred’uje na severnej strane lokality, pri viditelných ruinách stavieb z nepálených tehiel (surovíc) na rozhraní s nílskou nivou. Skúmané črepy neboli dostatočne diagnostické, a preto ich ani nebolo možné chronologicky zaradit. Pravdepodobne pochádzajú z viacerých časových úsekov.

Okrem črepového materiálu prieskum na lokalite identifikoval aj sporadické úlomky alabastru, čiernej, červenej žuly a kamenné úštepy. Dva nálezy čiernej žuly niesli znaky obrusu, pravdepodobne sa mohli používat ako zrnotierky. Alabaster a žula boli v staroegyptskej tradícií využívané na sakrálne a funerálne účely (Lucas 1959, 66, 72-77, 463, 469 n).

Prieskum v palmovom háji pri severnom okraji lokality odhalil vel'ký opracovaný triangloidný blok z čiernej žuly, s okrúhlym otvorom v centrálnej časti bloku.

Archeologický výskum na lokalite Duwejm Wad Hadž má naplánované d’alšie bádatel'ské sezóny. Geofyzikálnymi metódami overí identifikované situácie a zameria sa aj na pokračovanie archeologického prieskumu okolia.

\section{LITERATÚRA}

Abdelrahman 2014

Edwards 2004

Edwards 2007

Elsadig 2000

El-Zein 2000

Fahmi 2014

Greenlaw 2015

Griffith 1922

Griffith 1923

Hattstein/Delius 2007

Hudec 2017

Kendall 1990

Kendall 2002

Kendall 2010

Lucas 1959

Salomon 2016

Smith 2013

Trimingham 1965
A. M. Abdelrahman: The Islamic Period in the Fourth Cataract. In: J. R. Anderson/D. A. Welsby (ed.): The Fourth Cataract and Beyond. Proceedings of the $12^{\text {th }}$ International Conference for Nubian Studies. Peeters: Leuven - Paris - Walpole 2014, 201-208. D. N. Edwards: The Nubian Past. An Archaeology of the Sudan. London - New York 2004.

D. N. Edwards: The Archaeology of Sudan and Nubia. Annual Review of Anthropo$\log y 36,2007,211-228$.

S. O. Elsadig: The Domed Tombs of the Eastern Sudan. In: Sudan \& Nubia. Bulletin of the Sudan Archaeological Research Society 4. London 2000, 37-43.

I. S. El-Zein: The Archaeology of the Early Islamic Period in the Republic of Sudan. In: Sudan \& Nubia. Bulletin of the Sudan Archaeological Research Society 4. London 2000, 32-36.

W. S. Fahmi: The Adaptation Process of a Resettled Community to the Nerwly-Built Environment. A Study of the Nubian Experience in Egypt. Boca Raton 2014.

J. P. Greenlaw: The Coral Buildings of Suakin. Routledge, Oxon - New York 2015.

F. L. Griffith: Oxford Excavations in Nubia. Liverpool Annals of Archaeology and Anthropology 9, 1922, 67-124.

F. L. Griffith: Oxford Excavations in Nubia. Liverpool Annals of Archaeology and Anthropology 10, 1923, 73-171.

M. Hattstein/P. Delius (ed.): Islam. Art and Architecture. Cairo 2007.

J. Hudec: Informácia z návštevy lokality Duwejm Wad Hadž. Výskumná správa. Bratislava 2017. Nepublikované.

T. Kendall: Discoveries at Sudan's Sacred Mountain of Jebel Barkal Reveal Secrets of the Kingdom of Kush. National Geographic Society, New York 1990.

T. Kendall: Napatan Temples: A Case Study from Gebel Barkal. rmcisadu.let.uniroma1. it/nubiaconference/kendall.doc [2. 10. 2018].

T. Kendall: Jebel Barkal History and Archaeology of Ancient Napata. http://jebelbarkal.org /index.php?option=com_content\&view $=\% 20$ article\&id=67\&Itemid=77 [2. 10. 2018].

A. Lucas: Ancient Egyptian Materials and Industries. London 1959.

N. Salomon: For Love of the Prophet: An Ethnography of Sudan's Islamic State. Princeton - Oxford 2016.

L. Smith et al.: Archaeological Work at Suakin. Fondation Max van Berchem. Sudan 2013. https://maxvanberchem.org/fr/activites-scientifiques/projets/archeologie/11-archeologie/57-archaeological-work-at-suakin [2. 10. 2018].

J. S. Trimingham: Islam in the Sudan. Wadi Abu Dom Itinerary. Westfälische Wilhelms-Universität Münster. London1965. http://en.wadi-abu-dom.de/ [2. 10. 2018]. 

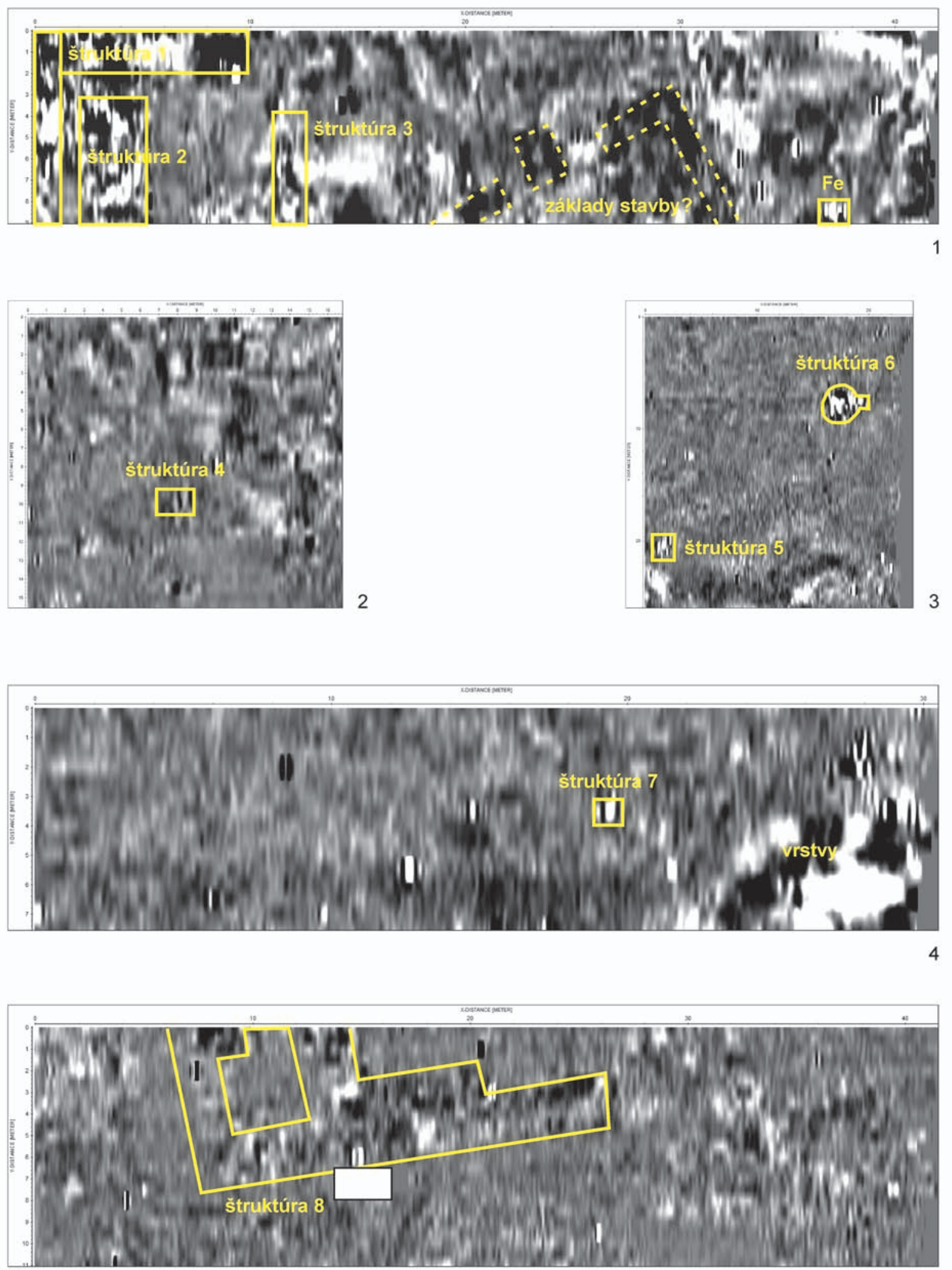

Tab. I. Duwejm Wad Hadž. Geofyzikálny výskum. 1- plocha 1, horizontálny časový rez pre híbku $55 \mathrm{~cm}$; 2- plocha 2, horizontálny časový rez s híbkou $55 \mathrm{~cm}$; 3- plocha 3, horizontálny časový rez s híbkou $60 \mathrm{~cm}$; 4- plocha 4, horizontálny časový rez s híbkou $60 \mathrm{~cm}$; 5- plocha 5a, horizontálny časový rez s híbkou $130 \mathrm{~cm}$. 


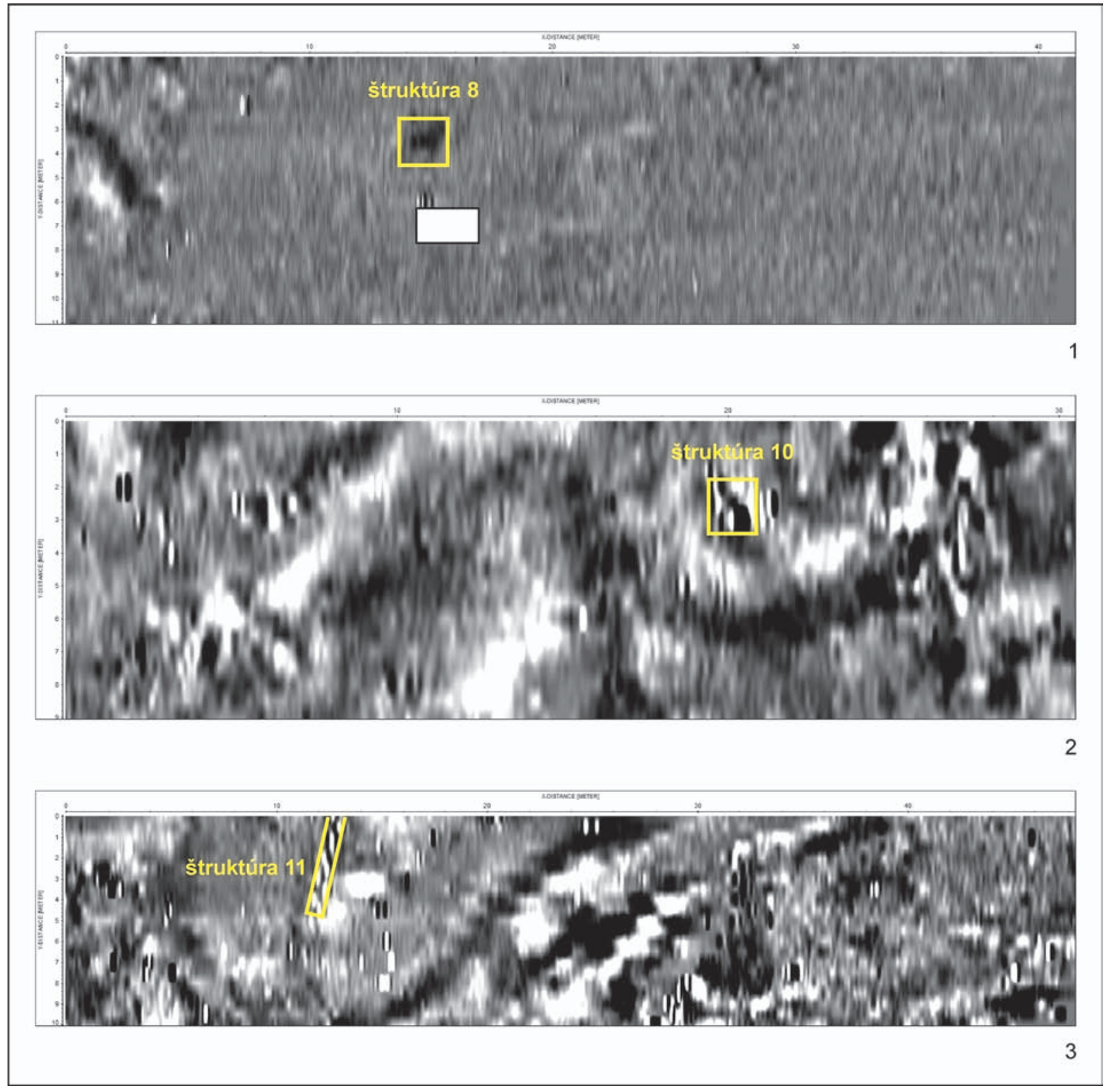

Tab. II. Duwejm Wad Hadž. Geofyzikálny výskum. 1- plocha 5a, horizontálny časový rez s híbkou 200 cm; 2- plocha 5b, horizontálny časový rez s híbkou $55 \mathrm{~cm}$; 3- plocha 6, horizontálny časový rez s híbkou $55 \mathrm{~cm}$. 


\title{
Research at Duweym Wad Haj in the Sudan in 2017 and 2018 Seasons
}

\author{
Jozef Hudec - Michal Cheben - Branislav Kovár
}

\author{
Summary
}

The article provides a preliminary report on the first survey and research seasons at the Sudanese site of Duweym Wad Hajj. "The Slovak research at the Sudanese site of Duweym Wad Hajj” is a joint project of the Institute of Oriental Studies, Slovak Academy of Sciences (SAS) in Bratislava, Slovakia, the Archaeological Institute, SAS in Nitra, Slovakia, and the Aigyptos Foundation, Žitavany, Slovakia.

Duweym Wad Haj is located in the Northern State (Wilayet ash-Shamaliya), about $350 \mathrm{~km}$ north of Khartoum, in the Great Nile Bend, on the left bank of the Nile River, about $30 \mathrm{~km}$ south-west, i.e. downstream from the Merowe Dam, which was built on the Fourth Nile Cataract. Duweym is located close to the well-known ancient archaeological sites of Gebel Barkal and Sanam, and other UNESCO sites of the region.

The site was discovered by an earlier survey made by the Sudanese archaeologist Faiz Hassan Osman and later reported by the U. S. archaeologist Timothy Kendall. J. Hudec accomplished a short survey at the site in November 2017 (Hudec 2017).

Duweym Wad Haj is a small tell on and beside a sandstone ridge. The tell exceeds ca. 5 to $6 \mathrm{~m}$ above the surrounding terrain, at the dividing line between the Nile floodplain and the desert terraces. Two mosques and a qubba (tomb of an Islamic pious man covered by a dome) are located on the sandstone ridge. The Islamic architectures are not dated precisely. The older, northern mosques is in a desolate state, mainly retaining parts of its carrying walls. The southwestern corner of the older mosque was demolished and its area is occupied by a new mosque, constructed at the end of $20^{\text {th }}$ century. The southern wall of the old mosque collapsed. The other walls have been preserved to the level of a former roof.

Preserved western entrance to the older mosque is mirror-flanked by hard stone blocks (probably of black granite), one on each side, at the level of the upper stair. It is not excluded that both stones once formed a longer prismatic block. They are both green painted on the frontal sides, much like the gate of the mosque. On the left side of the gate, in front of the carrying wall, there is a worked stone block of the same material as the blocks mentioned above. It might be a torso of a temple staircase. All mentioned stone blocks might come from an earlier building(s) under the mosque, or they could be brought from nearby sites (e. g. Gebel Barkal, Sanam). The old mosque was rudimentary documented in the 2018 season and it will be an object for further researches.

Surroundings and the interior of the old mosque were covered by (drifted-in?) fine yellow sand. There was a layer of gravel, containing few small fragments of ceramics, eastwards of the old mosque.

Pot-sherds were found mainly concentrated on the northern side of the tell. Discovered fragments were not diagnostic enough to allow chronological classification of the ceramic, which might probably come from several time slots. In addition to ceramic finds, sporadic fragments and pieces of alabaster, black and red granite and stone industry were identified during the site survey. Two pieces of the black granite displayed some abrasion, they might be used as grinders.

Geophysical research, architectural documentation of the older mosque and archaeological prospecting was done at Duweym Wad Haj from February 21 to February 25, 2018.

A geophysical survey was carried out using a georadar. The purpose of the geophysical survey was to identify remains of assumed ancient architecture. The survey used Ground Penetration Radar/GPR (RAMAC) X3M system with $500 \mathrm{MHz}$ antenna. Individual profiles in $0.5 \mathrm{~m}$ distances from each other were measured in designated areas. After processing by ReflexW software, the measured vertical georadar profiles were merged into horizontal time slides. The field depth of the antenna's reach was set to $3.4 \mathrm{~m}$. The individual areas were geodetically measured out by GPS Trimble R2 after the geophysical measurements.

The geophysical survey was situated on marked terrain elevation inside the area of the defunct old mosque, as well as eastwards and northwards of it. The area of research was split into 8 areas. On the terrain's surface was a layer of sand (mixed with clay), which was deposited on a sandstone bedrock. The situation was different with two areas (No. 6 and 7), where the upper layer of sand-clay mix was deposited on the fluvial clays of the Nile River.

After a processing of the data measured in the individual areas by the above mentioned software and elaboration of horizontal time slots, several structures appeared on the slots, indicating archaeological situations, some of which might be traces of ancient architectures. Overall, 11 structures were recovered which could indicate ancient settlement.

During a survey of surrounding area a large triangle block of worked black granite with a round hole in its central part was discovered in a palm grove at the northern periphery of the site.

Archaeological research at Duweym Wad Haj is being planning further research seasons. The research will verify the results of geophysical methods and will also continue in the archaeological survey. 
Fig. 1. Duwejm Wad Hadž. Location of the site on Google Earth.

Fig. 2. Duwejm Wad Hadž. The younger mosque and gubba. Photo by B. Kovár.

Fig. 3. Duwejm Wad Hadž. Preserved northern wall of the older mosque. Photo by B. Kovár.

Fig. 4. Duwejm Wad Hadž. Painted stone block on the left side of the western entrance gate. Photo by J. Hudec.

Fig. 5. Duwejm Wad Hadž. Geophysical survey with Ground Penetration Radar. Photo by B. Kovár.

Fig. 6. Duwejm Wad Hadž. Area of the geophysical survey. Photo by M. Cheben.

Fig. 7. Duwejm Wad Hadž. Preserved remains of the riwāq. Photo by J. Hudec.

Fig. 8. Duwejm Wad Hadž. Mihrab lined with an ornamental frame on the wall between a window and the minbar. Photo by J. Hudec.

Fig. 9. Duwejm Wad Hadž. Preserved northern wall of the old mosque. Photo by J. Hudec.

Fig. 10. Duwejm Wad Hadž. False entrance shaped in the masonry of the outer side of the western wall. Photo by J. Hudec.

Fig. 11. Duwejm Wad Hadž. Cross-section of brick bond and the wall in the southeastern corner of the mosque. Photo by J. Hudec.

Pl. I. Duwejm Wad Hadž. Geophysical survey. 1 - area 1, horizontal chronological cross-section with depth of $55 \mathrm{~cm}$; 2 - area 2, horizontal chronological cross-section with depth of $55 \mathrm{~cm} ; 3$ - area 3, horizontal chronological crosssection with depth of $60 \mathrm{~cm} ; 4$ - area 4 , horizontal chronological cross-section with depth of $60 \mathrm{~cm} ; 5$ - area $5 \mathrm{a}$, horizontal chronological cross-section with depth of $130 \mathrm{~cm}$.

Pl. II. Duwejm Wad Hadž. Geophysical survey. 1 - area 5b, horizontal chronological cross-section with depth of $200 \mathrm{~cm}$; 2 - area $5 b$, horizontal chronological cross-section with depth of $55 \mathrm{~cm} ; 3$ - area 6, horizontal chronological crosssection with depth of $55 \mathrm{~cm}$.

Translated by Mgr. Jozef Hudec, PhD., Mgr. Branislav Kovár, PhD. and Mgr. Viera Tejbusová

Mgr. Jozef Hudec, ${ }^{6} \mathrm{PhD}$.

Ústav orientalistiky SAV

Klemensova 19

SK - 81364 Bratislava

jozef.hudec@savba.sk

Mgr. Branislav Kovár, PhD.

Archeologický ústav SAV

Akademická 2

SK - 94921 Nitra

branislav.kovar@savba.sk
Mgr. Michal Cheben

Archeologický ústav SAV

Akademická 2

SK - 94921 Nitra

michal.cheben@savba.sk

6 Tiež predseda Správnej rady Nadácie Aigyptos. 